\title{
SISTEM INFORMASI INVENTARIS BARANG Berbasis Web MengGunaKan LaRaVEL PaDA DiNAS KePENDUDUKAN DAN PENCATATAN SIPIL SINTANG
}

\author{
Muhammad Iqbal $^{1}$, Ibnur Rusi ${ }^{2}$, dan Ferdy Febriyanto ${ }^{3)}$ \\ ${ }^{1,2,3)}$ Prodi Sistem Informasi, Fakultas MIPA Universitas Tanjungpura \\ e-mail: iqbalmtgjr@gmail.com ${ }^{1)}$, ibnurrusi@ sisfo.untan.ac.id ${ }^{2}$, ferdyf@ $@$ sisfo.untan.ac.id $^{3)}$
}

\begin{abstract}
Abstrak: Inventarisasi yang baik, sistematis, dan terstruktur atas barang yang ada pada suatu kantor atau lembaga merupakan hal yang wajib dilakukan, karena dengan adanya inventarisasi barang yang sistematis akan mengakibatkan proses kerja menjadi lebih efektif dan efisien. Sistem inventarisasi barang pada Dinas Kependudukan dan Pencatatan Sipil (Disdukcapil) Sintang saat ini perlu untuk dikembangkan. Penelitian ini bertujuan untuk mengembangakan perangkat lunak berbasis website guna memudahkan dalam perencanaan, pengadaan, penyaluran, dan pemusnahan/penghapusan atas barang-barang yang ada di Disdukcapil Sintang. Pengembangan sistem informasi berbasis website ini dilakukan dengan menggunakan Framework Laravel dan Bootsrap serta database MySQL. Metode pengembangan sistem yang digunakan dalam pembuatan sistem informasi ini adalah SDLC (System Development Life Cycle) Waterfall menggunakan model Hefner. Penelitian ini diharapkan dapat membantu pihak Disdukcapil dalam melakukan inventarisasi barang milik kantor pemerintah sehingga menjadi lebih terstruktur dan sistematis untuk mencapai efisiensi dan efektifitas kinerja pegawai Disdukcapil Sintang.
\end{abstract}

Kata Kunci-Sistem Informasi, Inventarisasi, Disdukcapil, Laravel

\section{PENDAhUluan}

$\mathrm{D}$ inas Kependudukan dan Pencatatan Sipil merupakan unsur pelaksana Pemerintah Daerah di bidang Kependudukan dan Pencatatan Sipil yang dipimpin oleh Kepala Dinas dan berkedudukan di bawah dan bertanggungjawab kepada Bupati melalui Sekretaris Daerah. Dinas Kependudukan dan Pencatatan Sipil mempunyai tugas melaksanakan urusan rumah tangga Pemerintah Daerah dan tugas pembantuan di bidang Kependudukan dan Pencatatan Sipil. Untuk mendukung kinerja dari pegawai instansi ini dibutuhkan inventaris barang untuk bisa digunakan dalam bekerja seperti perlengkapan kantor, laptop/pc, printer, kendaraan, dan lain sebagainya

Inventarisasi barang merupakan pencatatan data yang berhubungan dengan barang atau aset dalam instansi. Umumnya kegiatan dalam inventarisasi barang adalah pencatatan pengadaan barang, penempatan, mutasi dan pemeliharaan. Setiap barang yang ingin diadakan harus dicatat dengan baik begitu juga jika barang yang sudah diadakan dan disalurkan harus dicatat dan dilaporkan dengan baik dan benar sebagai data aset pemerintah.

Dinas Kependudukan dan Pencatatan Sipil (Disdukcapil) Sintang memerlukan pelaporan mengenai inventaris barang yang direncanakan, pengadaan barang, penyaluran barang maupun penghapusan barang. Pembuatan laporan inventarisasi barang pada instansi ini masih belum optimal yakni pada pembuatan laporan perencanaan barang, pengadaan barang maupun penyaluran barang yang bisa dikatakan kurang efektif dan efisien dalam pelaksanaannya. Untuk mengatasi permasalahan yang ada terkait inventarisasi barang pada Disdukcapil Sintang, maka dibutuhkan sistem informasi inventarisasi barang sehingga dapat mempermudah dan mempercepat kinerja pegawai di Disdukcapil Sintang. 
Sistem informasi yang dibuat adalah Sistem informasi inventaris yang merupakan suatu sistem manajemen untuk mengelola barang-barang yang direcanakan, diadakan, disalurkan ataupun dihapuskan dalam manajemen pengelolaan barang yang ada di Disdukcapil Sintang.

\section{TINJAUAN PUSTAKA}

\section{A. Sistem Informasi}

Menurut O'Brien (2005, p5), sistem informasi adalah suatu kombinasi teratur apapun dari people (orang), hardware (perangkat keras), software (piranti lunak), computer networks and data communications (jaringan komunikasi), dan database (basis data) yang mengumpulkan, mengubah dan menyebarkan informasi di dalam suatu bentuk organisasi [1].

Penggunaan sistem informasi sangatlah penting bagi pihak yang akan melakukan dan menyelesaikan pekerjaannya secara cepat dan tepat. Menurut Turban bahwa penggunaan Sistem Informasi harus dapat meningkatkan efektivitas dan efisiensi orang-orang yang bekerja dalam suatu kelompok pada satu tempat atau beberapa tempat [2].

Terdapat komponen-komponen yang mendukung terbentuknya suatu sistem informasi. Kompenen pendukung tersebut meliputi:

1.Perangkat keras (hardware), mencakup, peranti-peranti fisik seperti komputer dan printer.

2. Perangkat lunak (software) atau program, yaitu sekumpulan instruksi yang memungkinkan perangkat keras untuk dapat memproses data.

3. Basis data (database) adalah sekumpulan tabel, hubungan dan lain-lain yang berkaitan dengan penyimpanan data.

4. Prosedur adalah sekumpulan aturan yang dipakai untuk mewujudkan sistem informasi, pemrosesan dan penggunaan keluaran sistem informasi.

5.Jaringan komputer dan komunikasi data, merupakan sistem penghubung yang memungkinkan sumber (resources) dipakai secara bersama atau diakses oleh sejumlah pemakai. [3]

\section{B. Inventarisasi}

Menurut Harsono, dkk (2004:163) Inventarisasi aset adalah kegiatan-kegiatan yang meliputi pendaftaran, pencatatan dalam daftar inventaris, penyusunan atau pengaturan barang-barang milik negara atau daerah serta melaporkan pemakaian barang-barang kepada pejabat yang berwenang secara teratur dan tertib menurut ketentuan dan tata cara yang berlaku sehingga mempermudah dalam penyajian data kekayaan negara/pemerintah daerah baik barang-barang tetap maupun barang-barang bergerak.[4]

Inventarisasi dibagi menjadi dua aspek, yaitu aspek fisik dan yuridis/legal. Aspek fisik terdiri atas bentuk, luas, lokasi, volume/jumlah, jenis, alamat dan lain-lain. Sedangkan aspek yuridis adalah status penguasaan, masalah legal yang dimiliki, batas akhir penguasaan. Proses kerja yang dilakukan adalah pendataan, kodifikasi/labelling, pengelompokkan dan pembukuan/administrasi sesuai dengan tujuan manajemen aset.[5]

\section{Laravel}

Laravel merupakan framework berbasis PHP yang dirilis oleh MIT yang menekankan kesederhanaan dan fleksibilitas pada desainnya. Laravel dibangun dengan konsep MVC (Model-ControllerView), kemudian dilengkapi juga dengan command line tool yang bisa digunakan untuk packaging bundle dan instalasi bundle melalui command prompt. Banyak sekali kelebihan-kelebihan yang dimiliki oleh framework Laravel. Adapun kelebihan framework Laravel adalah sebagai berikut:

$\checkmark$ Ekspressif

Laravel adalah framework PHP yang ekspressif, artinya ketika melihat suatu sintaks Laravel, seorang programmer akan langsung dapat mengetahui kegunaan dari sintaks tersebut meskipun belum pernah mempelajarinya sebelumnya. 
ANTIVIRUS: Jurnal Ilmiah Teknik Informatika (p - ISSN: 1978 - 5232; e - ISSN: 2527 - 337X)

Vol. 13 No. 2 November 2019, pp. $105-119$

$\checkmark$ Simple

Laravel dapat mengambil semua data yang ada di dalam table users, hanya dengan membuat sebuah class model bernama user, kemudian membuat kode sederhana untuk memasukan semua data dari tabel users tersebut. Hal ini dapat dilakukan karena pada Laravel terdapat Eloquent ORM yang memungkinkan untuk mengatasi hal tersebut.

$\checkmark$ Accessible

Laravel berusaha menjadi framework yang mudah digunakan (accessible) yakni dengan cara mengurangi tugas umum yang sering digunakan dalam beberapa pembuatan website seperti session, routing, maupun caching. [6]

\section{METODE PENELITIAN}

\section{A. Metode Pengembangan Sistem}

Metode penelitian yang digunakan dalam pengembangan sistem inventarisasi barang pada Disdukcapil Sintang adalah SDLC (System Development Life Cycle) Waterfall. SDLC adalah proses mengembangkan atau mengubah suatu sistem perangkat lunak dengan menggunakan model-model dan metodologi yang digunakan orang untuk mengembangkan sistem-sistem perangkat lunak sebelumnya, berdasarkan best practice atau cara-cara yang sudah teruji baik [7]. Metode Waterfall dalam penelitian ini dikombinasikan dengan model Hefner, dengan maksud agar dalam memahami metode penelitan menjadi terarah dan lebih jelas. Adapun metode penelitian dalam penelitian ini adalah sebagai berikut:

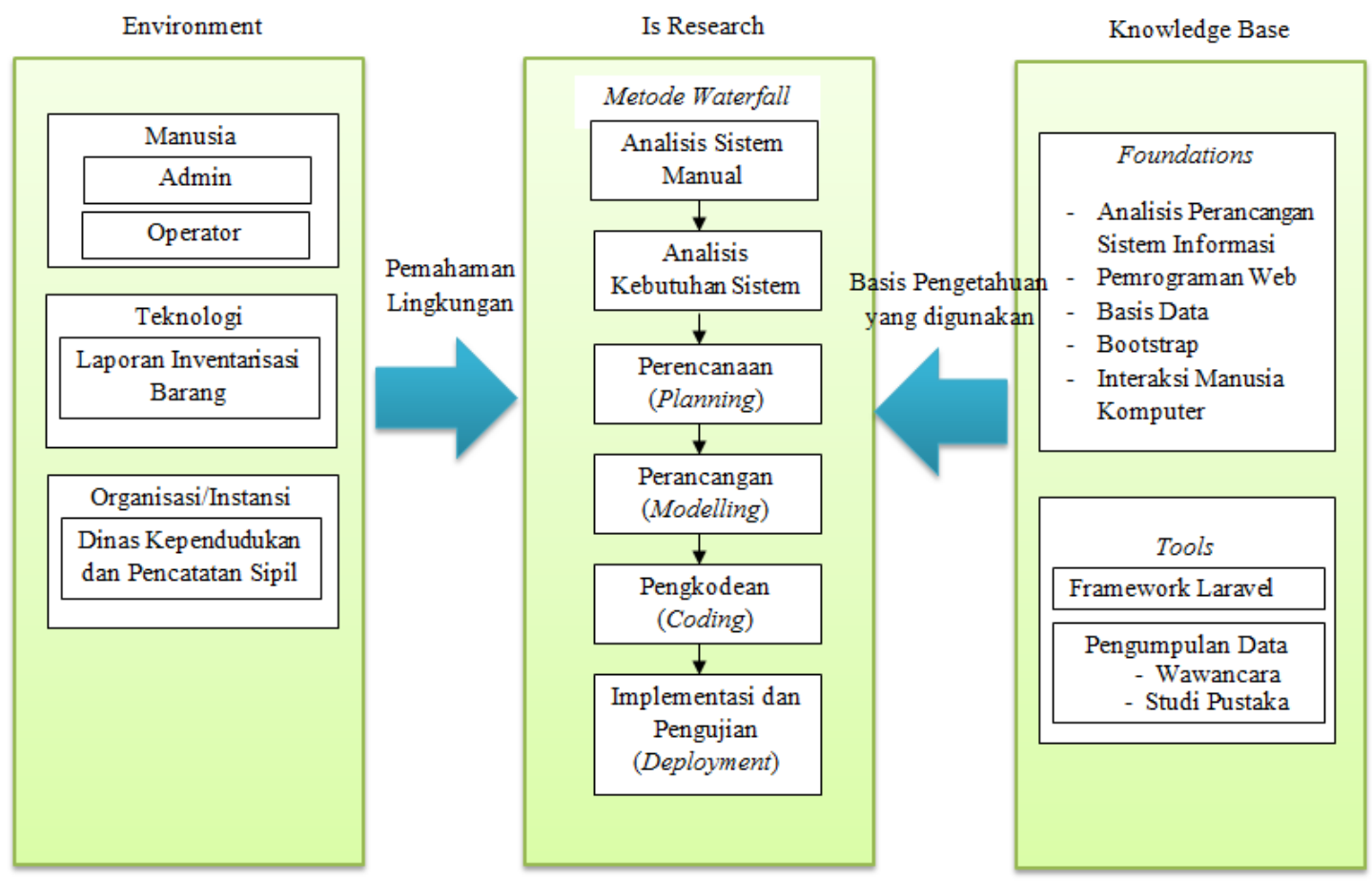

Gambar 1. Metode Waterfall pada Model Hefner

\section{B. Use Case Diagram}

Use Case Diagram merupakan rangkaian tindakan yang dilakukan oleh sistem, aktor mewakili user atau sistem lain yang berinteraksi dengan sistem yang dimodelkan [8]. Use case diagram yang terdapat dalam penelitian ini terdiri dari lima case yaitu, kelola perencanaan barang, kelola inventaris barang, kelola penyaluran barang, kelola barang rusak, dan kelola laporan barang. 


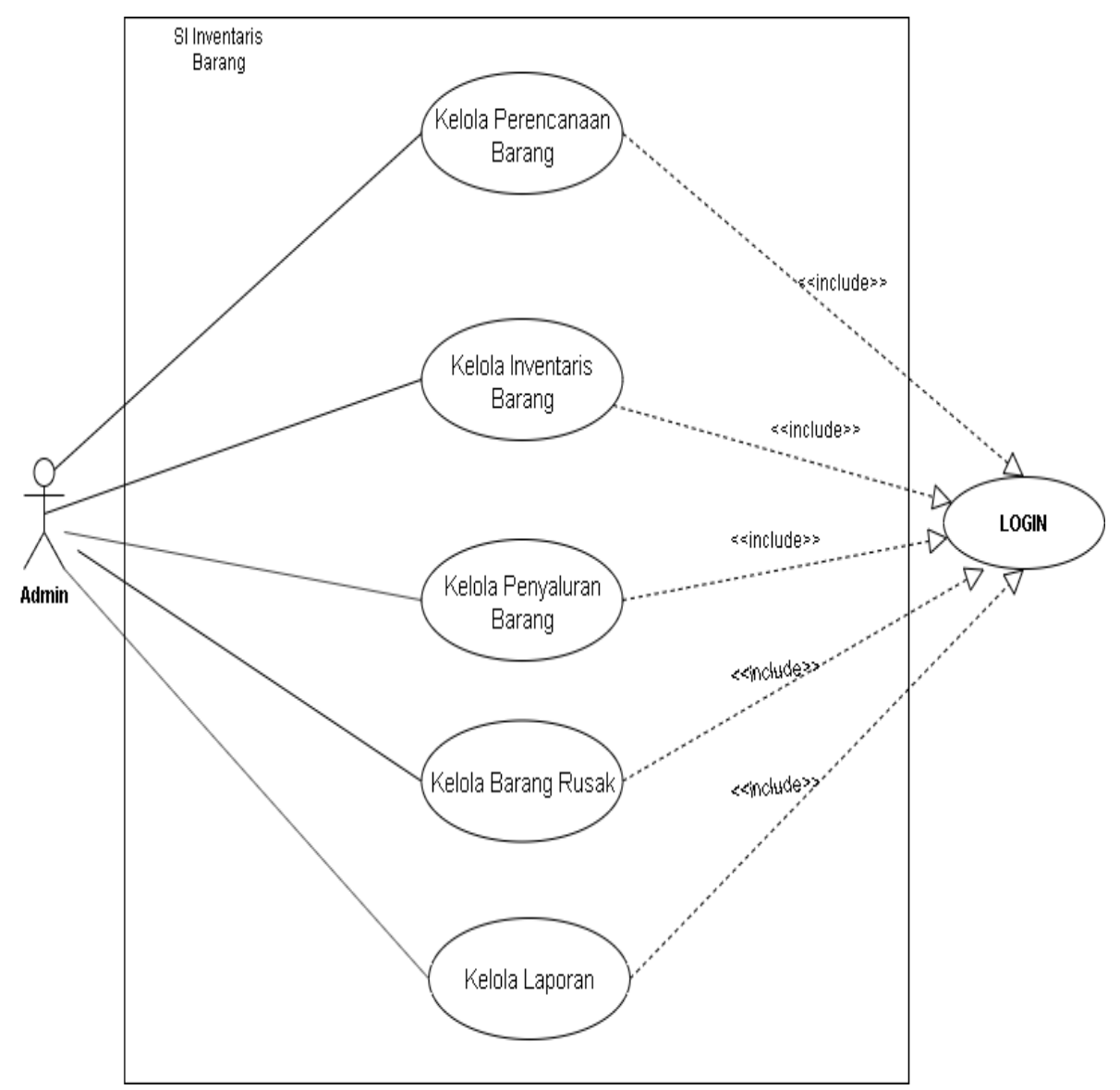

Gambar 2. Use Case Diagram

\section{Sequence Diagram}

Menurut Nugroho (2010), Sequence Diagram menjelaskan interaksi objek yang disusun dalam suatu urutan waktu. Sequence Diagram memperlihatkan tahapan yang seharusnya terjadi untuk menghasilkan sesuatu [9]. Dalam sistem informasi inventarisasi barang pada penelitian ini terdapat sequence diagram umum sesuai dengan use case diagram.

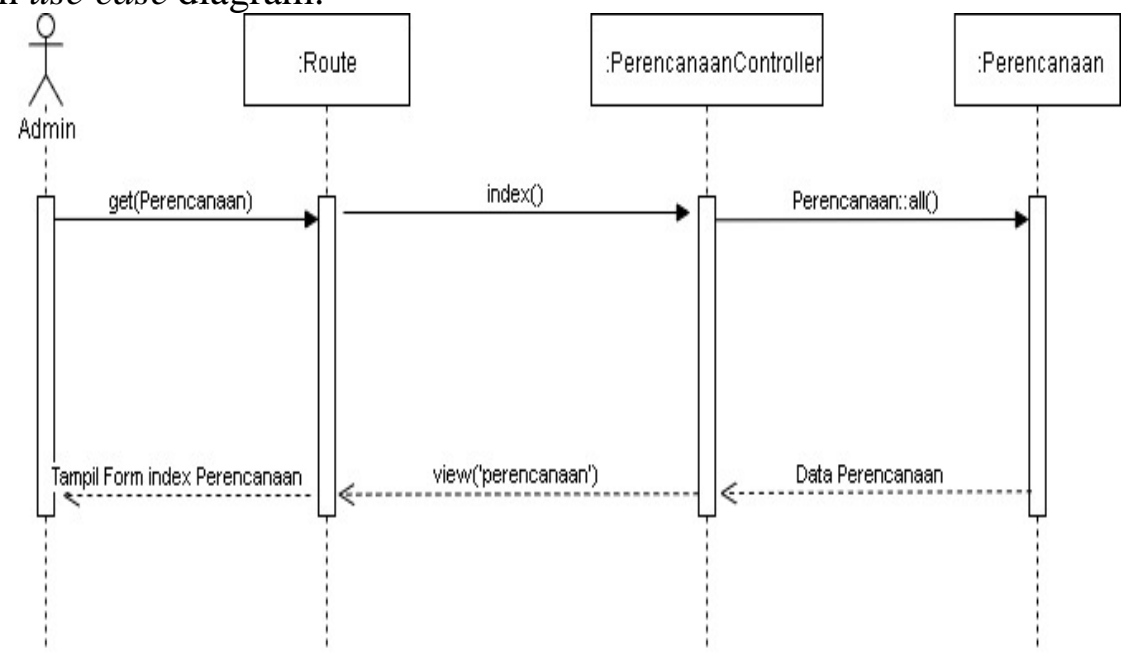

Gambar 3. Sequence Diagram Kelola Perencanaan 
ANTIVIRUS: Jurnal Ilmiah Teknik Informatika (p - ISSN: 1978 - 5232; e - ISSN: 2527 - 337X)

Vol. 13 No. 2 November 2019, pp. $105-119$

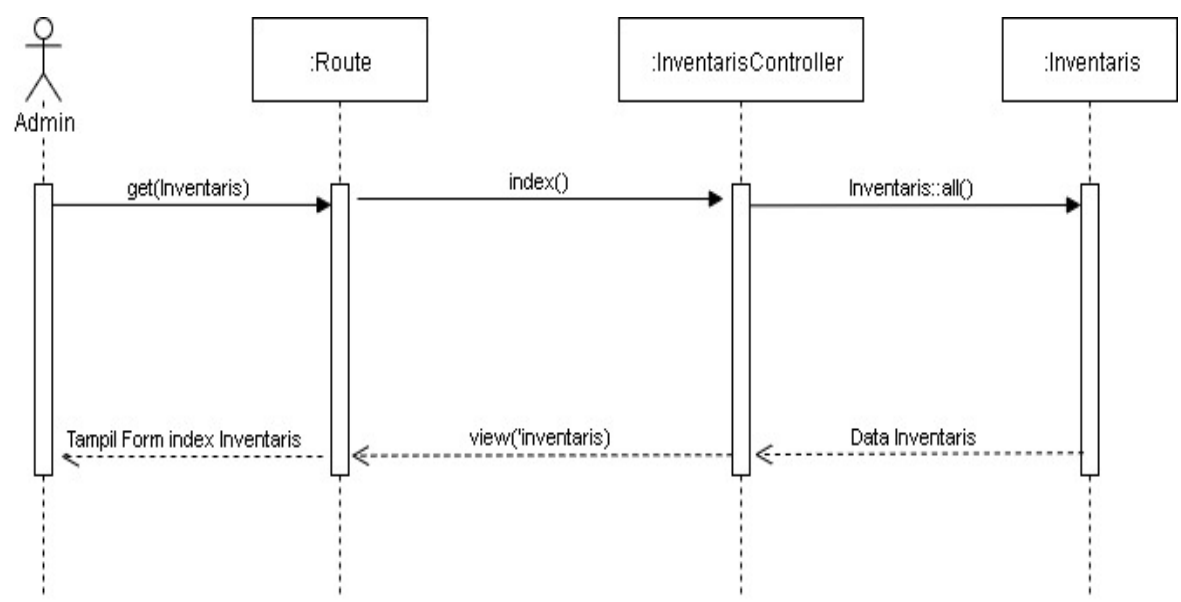

Gambar 3. Sequence Diagram Kelola Inventaris

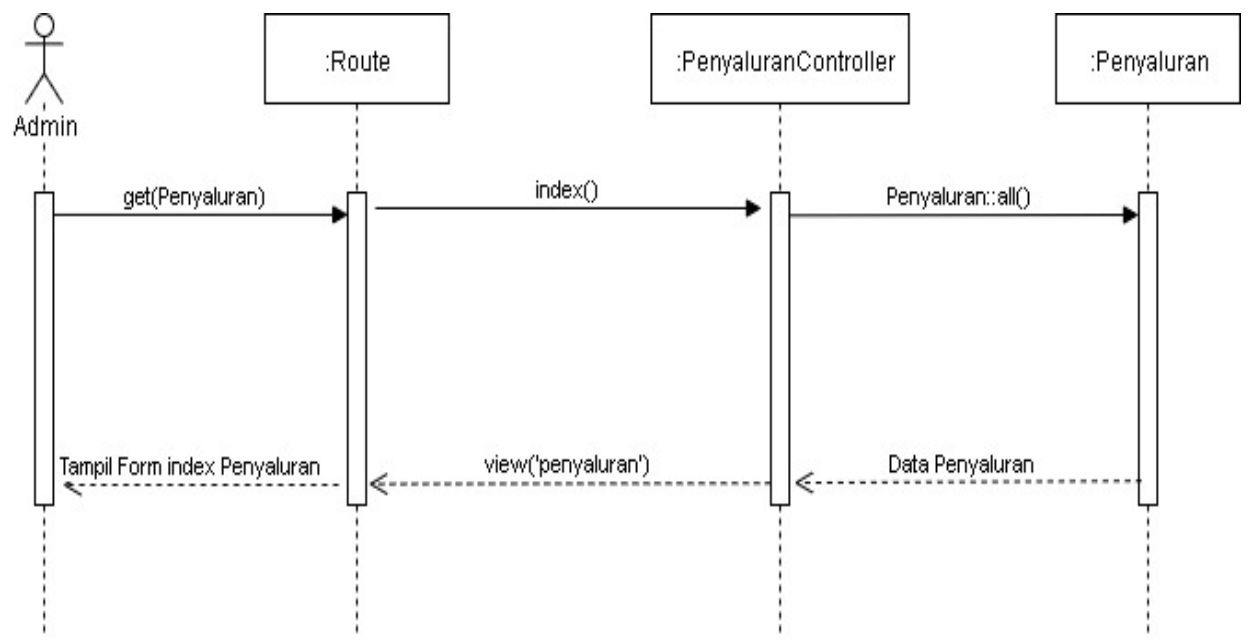

Gambar 4. Sequence Diagram Kelola Penyaluran

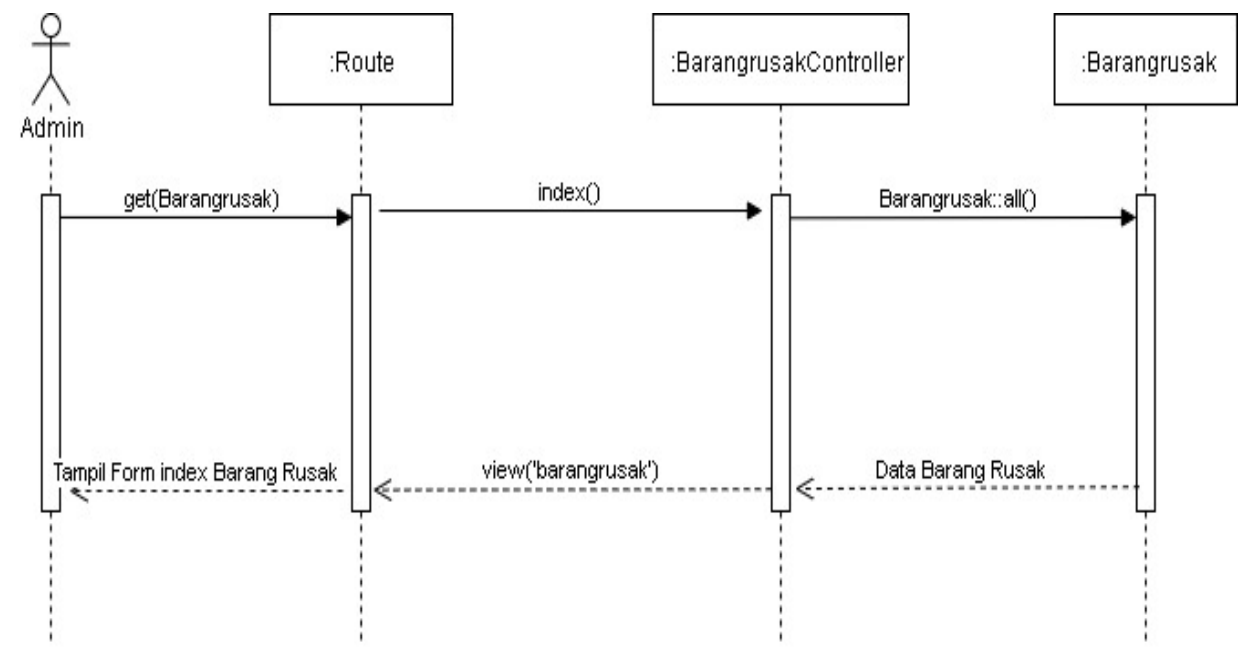

Gambar 5. Sequence Diagram Kelola Barang Rusak

\section{Class Diagram}

Class Diagram menggambarkan struktur sistem dari segi pendefinisian kelas-kelas yang akan dibuat untuk membangun sistem [10]. Kelas-kelas yang terdapat dalam sistem inventaris barang ini meliputi kelas 
Admin, Perencanaan, Jenis Barang, Inventaris Barang, Penyaluran Barang, dan Penyimpanan Barang Rusak.
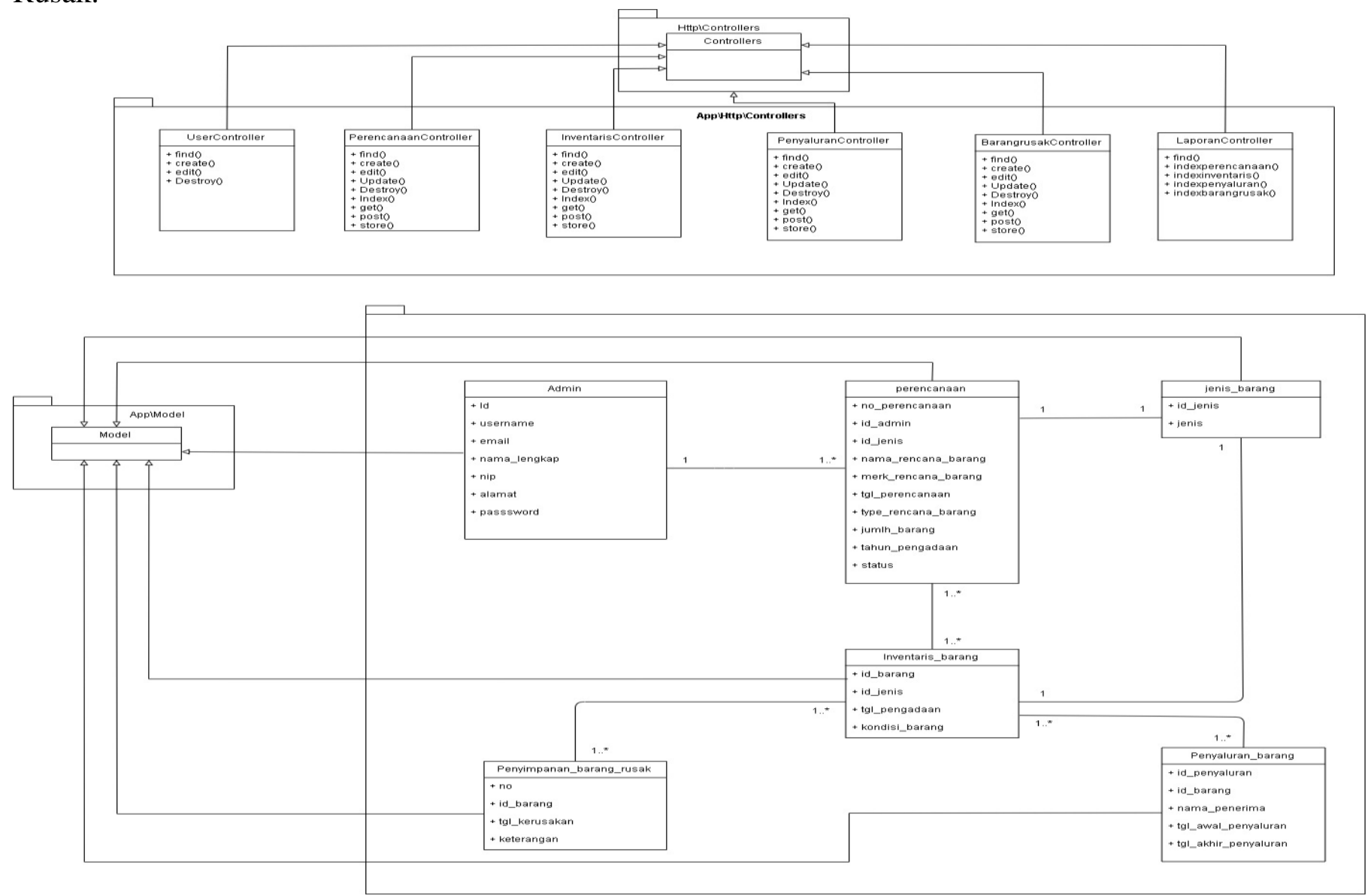

Gambar 6. Class Diagram

\section{HASIL DAN PEMBAHASAN}

\section{A. Pengujian Sistem}

\section{a. Pengujian Fungsionalitas}

Pengujian fungsionalitas merupakan pengujian yang dilakukan untuk mengetahui sejauh mana fungsi-fungsi yang ada pada sistem dapat berjalan. Dalam penelitian ini pengujian fungsionalitas terhadap sistem menggunakan metode pengujian Blackbox Testing. Blackbox Testing merupakan metode untuk menguji perangkat lunak dari segi spesifikasi fungsional, tanpa menguji desain dank ode program [11]. Pengujian Fungsionalitas dari sistem inventaris barang dalam penelitian ini meliputi pengujian login, pengelolaan barang (perencanaan, inventaris, dan penyaluran), pencarian barang (perencanaan, inventaris, dan penyaluran), dan filterisasi barang (perencanaan, pengadaan/inventaris, penyaluran, dan jenis barang).

TABEL 1

TABEL PENGUJIAN FUNGSIONALITAS SISTEM

\begin{tabular}{clll}
\hline No & Item Uji & Teknik Uji & Fungsi yang diuji \\
\hline 1 & Login & Blackbox Testing & Username, Password \\
2 & Pencarian Barang & Blackbox Testing & $\begin{array}{l}\text { Pencarian pada perencanaan barang } \\
\text { Pencarian pada penyaluran barang }\end{array}$ \\
3 & Filterisasi Barang & Blackbox Testing & Filterisasi pada \\
\hline
\end{tabular}




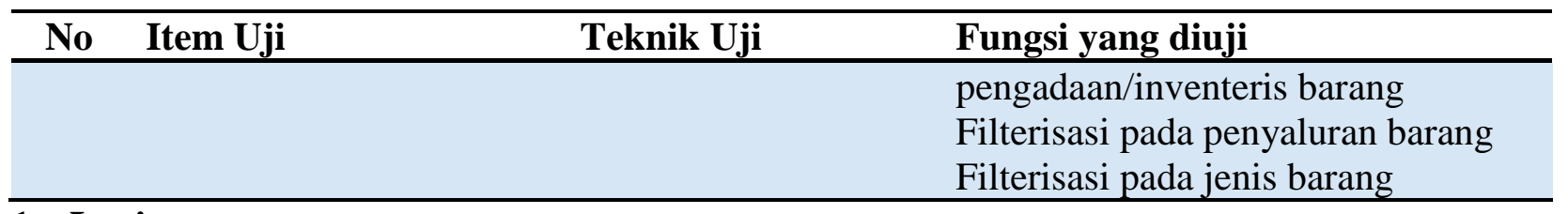

1. Login

Pengujian fungsi pada login dimaksudkan untuk memeriksa hak akses dari admin sistem melalui pendeteksian username dan password. Jika username dan/atau password kosong maka user tidak dapat masuk ke sistem, demikian jika username dan/atau password salah user juga tidak dapat masuk dan mengakses system.

TABEL 2

TABEL PENGUJIAN LOGIN

\begin{tabular}{clll}
\hline No & Atribut Input & Inputan & Hasil \\
\hline 1 & Username & Kosong & Akses ditolak \\
& Password & Kosong & Login Gagal! \\
2 & Username & Benar & Akses ditolak \\
& Password & Salah & Login Gagal! \\
3 & Username & Salah & Akses ditolak \\
& Password & Benar & Login Gagal! \\
4 & Username & Benar & Akses Berhasil \\
& Password & Benar & Login Sukses! \\
\hline
\end{tabular}

\section{Pencarian Barang}

\section{$\checkmark$ Perencanaan Barang}

Fungsi pencarian barang digunakan untuk mempermudahan dalam melakukan pencarian barang, sehingga user/admin tidak perlu mengecek satu per satu ketika akan melakukan pencarian barang. Fungsi ini perlu diuji untuk memastikan apakah hasil yang ditampilkan dari pencarian barang sesuai dengan barang yang dicari. Dalam pengujian ini item yang dicontohkan hanya perencanaan barang.

TABEL 3

TABEL PENGUJIAN PENCARIAN BARANG

\begin{tabular}{lllll}
\hline No & Atribut Input & $\begin{array}{l}\text { Data di } \\
\text { Database }\end{array}$ & $\begin{array}{l}\text { Data yang } \\
\text { dicari }\end{array}$ & Hasil \\
\hline 1 & No Perencanaan & 1101 & & \\
& Id Admin & 12345 & & \\
& Id Jenis & 1 & & Data Tidak \\
& Nama Rencana Barang & Printer & & Ditemukan. \\
& Merk Rencana Barang & Canon & Epson & Pencarian Gagal! \\
& Tanggal Perencanaan & $16 / 10 / 2019$ & & \\
& Type Rencana Barang & IP 2770 & & \\
& Jumlah Barang & 2 & & \\
& Tahun Pengadaan & 2020 & & \\
& Status & Perencanaan & & Data Ditemukan. \\
2 & No Perencanaan & 1101 & & Pencarian Sukses! \\
& Id Admin & 12345 & Canon & \\
& Id Jenis & 1 & & \\
& Nama Rencana Barang & Printer & & \\
\hline
\end{tabular}




\begin{tabular}{lllll}
\hline No & Atribut Input & $\begin{array}{l}\text { Data di } \\
\text { Database }\end{array}$ & $\begin{array}{l}\text { Data yang } \\
\text { dicari }\end{array}$ & Hasil \\
\hline & Merk Rencana Barang & Canon & & \\
Tanggal Perencanaan & $16 / 10 / 2019$ & & \\
Type Rencana Barang & $I P 2770$ & \\
Jumlah Barang & 2 & \\
Tahun Pengadaan & 2020 & \\
Status & Perencanaan & \\
\hline
\end{tabular}

\section{Filterisasi Barang}

Fungsi dari filter barang adalah untuk melakukan penyaringan barang sesuai dengan yang diinputkan oleh user/admin. Filter barang mempermudah user/admin dalam memproses data, sehingga data yang dibutuhkan akan keluar dan terfilter sesuai dengan apa yang diinput oleh user/admin. Untuk filterisasi barang dicontohkan tiga item, yaitu perencanaan barang, penyaluran barang, dan jenis barang.

\section{$\checkmark$ Perencanaan Barang}

TABEL 4

TABEL DATABASE FILTERISASI BARANG

\begin{tabular}{cllll}
\hline No & Atribut Input & \multicolumn{2}{l}{ Data di Database } & \\
\hline 1 & No Perencanaan & 1101 & 1102 & 1003 \\
& Id Admin & 12345 & 12345 & 12345 \\
& Id Jenis & 1 & 1 & 2 \\
& Nama Rencana Barang & Printer & Laptop & Printer \\
& Merk Rencana Barang & Canon & Lenovo & Epson \\
& Tanggal Perencanaan & $16 / 10 / 2019$ & $16 / 10 / 2019$ & $10 / 1 / 2018$ \\
& Type Rencana Barang & IP 2770 & G405 & M200 \\
& Jumlah Barang & 2 & 3 & 1 \\
& Tahun Pengadaan & 2020 & 2020 & 2019 \\
& Status & Perencanaan & Terealisasi & Terealisasi \\
\hline
\end{tabular}

Dari data diatas (Data di database) akan dilakukan filterisasi perencanaan barang berdasarkan statusnya, yaitu status barang yang sudah terealisasi.

TABEL 5

TABEL PENGUJIAN FILTERISASI PERENCANAAN BARANG

\begin{tabular}{|c|l|c|l|}
\hline No & \multicolumn{1}{|c|}{ Data di Database } & Filter data berdasarkan & \multicolumn{1}{|c|}{ Hasil yang muncul } \\
\hline 1 & 1101 & Status : & 1102 \\
& 12345 & "Terealisasi" & 12345 \\
& 1 & & 1 \\
& Printer & & Laptop \\
& Canon & & Lenovo \\
& $16 / 10 / 2019$ & $16 / 10 / 2019$ \\
& $I P 2770$ & & G405 \\
& 2 & 3 \\
& 2020 & & 2020 \\
& Perencanaan & Terealisasi \\
\hline
\end{tabular}


ANTIVIRUS: Jurnal Ilmiah Teknik Informatika (p - ISSN: 1978 - 5232; e - ISSN: 2527 - 337X)

Vol. 13 No. 2 November 2019, pp. 105 - 119

\begin{tabular}{|c|c|c|c|}
\hline No & Data di Database & Filter data berdasarkan & Hasil yang muncul \\
\hline & $\begin{array}{l} \\
\\
1102 \\
12345 \\
1 \\
\text { Laptop } \\
\text { Lenovo } \\
16 / 10 / 2019 \\
\text { G405 } \\
3 \\
2020 \\
\text { Terealisasi } \\
\\
1003 \\
12345 \\
2 \\
\text { Printer } \\
\text { Epson } \\
10 / 1 / 2018 \\
\text { M200 } \\
1 \\
2019 \\
\text { Terealisasi }\end{array}$ & & $\begin{array}{l}1003 \\
12345 \\
2 \\
\text { Printer } \\
\text { Epson } \\
10 / 1 / 2018 \\
\text { M200 } \\
1 \\
2019 \\
\text { Terealisasi }\end{array}$ \\
\hline
\end{tabular}

$\checkmark$ Inventaris/Pengadaan Barang 


\section{TABEL 6}

TABEL PENGUJIAN FILTERISASI INVENTARIS BARANG

\begin{tabular}{|c|c|c|c|}
\hline No & Data di Database & $\begin{array}{c}\text { Filter data } \\
\text { berdasarkan }\end{array}$ & Hasil yang muncul \\
\hline 1 & $\begin{array}{l}\text { Id Barang: 701080111 } \\
\text { Nama Brg: Kursi kerja } \\
\text { Merk Brg : Futura } \\
\text { Tgl Perencanaan : 19/9/2019 } \\
\text { Tipe Brg : 2112443 } \\
\text { Jenis Brg : - } \\
\text { Jumlah : } 3 \\
\text { Kondisi : Baik } \\
\text { Tgl Pengadaan : 14/10/2020 } \\
\text { Tahun Pengadaan : 2020 } \\
\text { Status : Terealisasi } \\
\text { Id Barang: 701080101 } \\
\text { Nama Brg: Bangunan B } \\
\text { Merk Brg : Bangunan Lokal } \\
\text { Tgl Perencanaan : 19/9/2019 } \\
\text { Tipe Brg : - } \\
\text { Jenis Brg : Gedung dan Bangunan } \\
\text { Jumlah : } 1 \\
\text { Kondisi : Baik } \\
\text { Tgl Pengadaan : } 14 / 10 / 2020 \\
\text { Tahun Pengadaan : 2020 } \\
\text { Status : Terealisasi } \\
\text { Id Barang: 701080103 } \\
\text { Nama Brg: Laptop } \\
\text { Merk Brg : Asus } \\
\text { Tgl Perencanaan : 19/9/2019 } \\
\text { Tipe Brg : Asus Au253 } \\
\text { Jenis Brg : Peralatan dan Mesin } \\
\text { Jumlah : 1 } \\
\text { Kondisi : Baik } \\
\text { Tgl Pengadaan : } 14 / 10 / 2020 \\
\text { Tahun Pengadaan : 2020 } \\
\text { Status : Terealisasi }\end{array}$ & $\begin{array}{l}\text { Tahun Pengadaan: } \\
\text { "2020" }\end{array}$ & $\begin{array}{l}\text { Id Barang: } 701080101 \\
\text { Nama Brg: Bangunan B } \\
\text { Merk Brg : Bangunan Lokal } \\
\text { Tgl Perencanaan : 19/9/2019 } \\
\text { Tipe Brg : - } \\
\text { Jenis Brg : Gedung dan } \\
\text { Bangunan } \\
\text { Jumlah : } 1 \\
\text { Kondisi : Baik } \\
\text { Tgl Pengadaan : 14/10/2020 } \\
\text { Tahun Pengadaan : 2020 } \\
\text { Status : Terealisasi }\end{array}$ \\
\hline
\end{tabular}




\begin{tabular}{|l|l|l|l|}
\hline No & \multicolumn{1}{|c|}{ Data di Database } & \multicolumn{1}{|c|}{$\begin{array}{c}\text { Filter data } \\
\text { berdasarkan }\end{array}$} & \multicolumn{1}{|c|}{ Hasil yang muncul } \\
\hline & Id Barang: 701080108 & & Jumlah : 1 \\
& Nama Brg: Komputer & & Kondisi : Baik \\
& Merk Brg : - & Tgl Pengadaan : 14/10/2020 \\
Tgl Perencanaan 01/10/2018 & & Tahun Pengadaan : 2020 \\
& Tipe Brg : - & Status : Terealisasi \\
& Jenis Brg : Komputer & \\
Jumlah : 10 & & \\
Kondisi : Baik & & \\
Tgl Pengadaan : 10/10/2019 & & \\
Tahun Pengadaan : 2019 & & \\
Status : Terealisasi & & \\
\hline
\end{tabular}

\section{b. Pengujian Kinerja Sistem}

Pengujian Kinerja Sistem digunakan untuk mengetahui lama dari proses saat dijalankan. Proses yang cepat dapat meningkatkan efisiensi dan efektifitas dari kinerja, sehingga mengakibatkan kepuasan dari user/admin semakin tinggi. Pengujian kinerja sistem dari penerapan sistem informasi inventaris pada penelitian ini terdiri dari dua item uji, yaitu pengujian kinerja proses pencarian data dan pengujian kinerja proses pelaporan inventaris barang.

TABEL 7

TABEL PENGUJIAN KINERJA SISTEM

\begin{tabular}{llccc}
\hline No & Proses Uji & $\begin{array}{c}\text { Waktu dengan } \\
\text { sistem lama }\end{array}$ & $\begin{array}{c}\text { Waktu dengan } \\
\text { sistem baru }\end{array}$ & Persentase \\
\hline 1 & $\begin{array}{l}\text { Proses Pencarian } \\
\text { Data }\end{array}$ & 20 menit & 3 detik & $99,75 \%$ \\
2 & $\begin{array}{l}\text { Proses Pelaporan } \\
\text { Inventaris Barang }\end{array}$ & 3 hari & 10 menit & $99,70 \%$ \\
\hline
\end{tabular}

\section{B. Antarmuka Pengujian Sistem}

\section{Login}

Hak akses untuk dapat masuk dan menggunakan sistem informasi inventaris barang hanya diberikan kepada user yang memiliki username dan password sesuai dengan yang terdapat di dalam database. Login akan sukses saat username dan/atau password sama dengan data yang ada didalam database. 


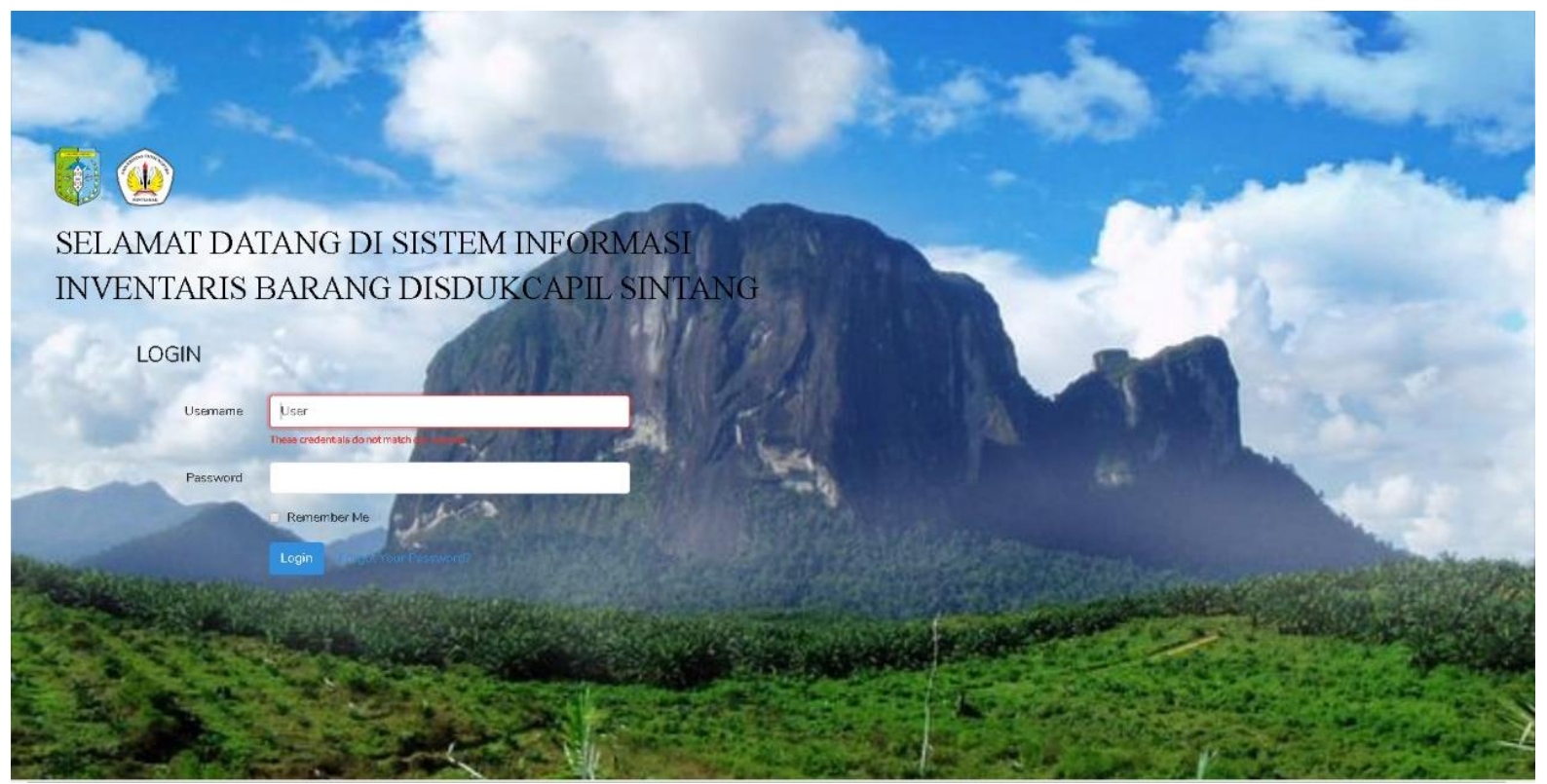

Gambar 7. Login Gagal

Gambar 7 memperlihatkan bahwa Login Gagal dikarenakan input username dan/atau password tidak match dengan database, sehingga akses untuk masuk ke dalam sistem tidak diizinkan. Gambar 8 memperlihatkan Login Sukses, menandakan username dan password yang diinputkan sesuai dengan database, dan sistem akan masuk ke beranda sehingga user/admin dapat mengakses sistem.

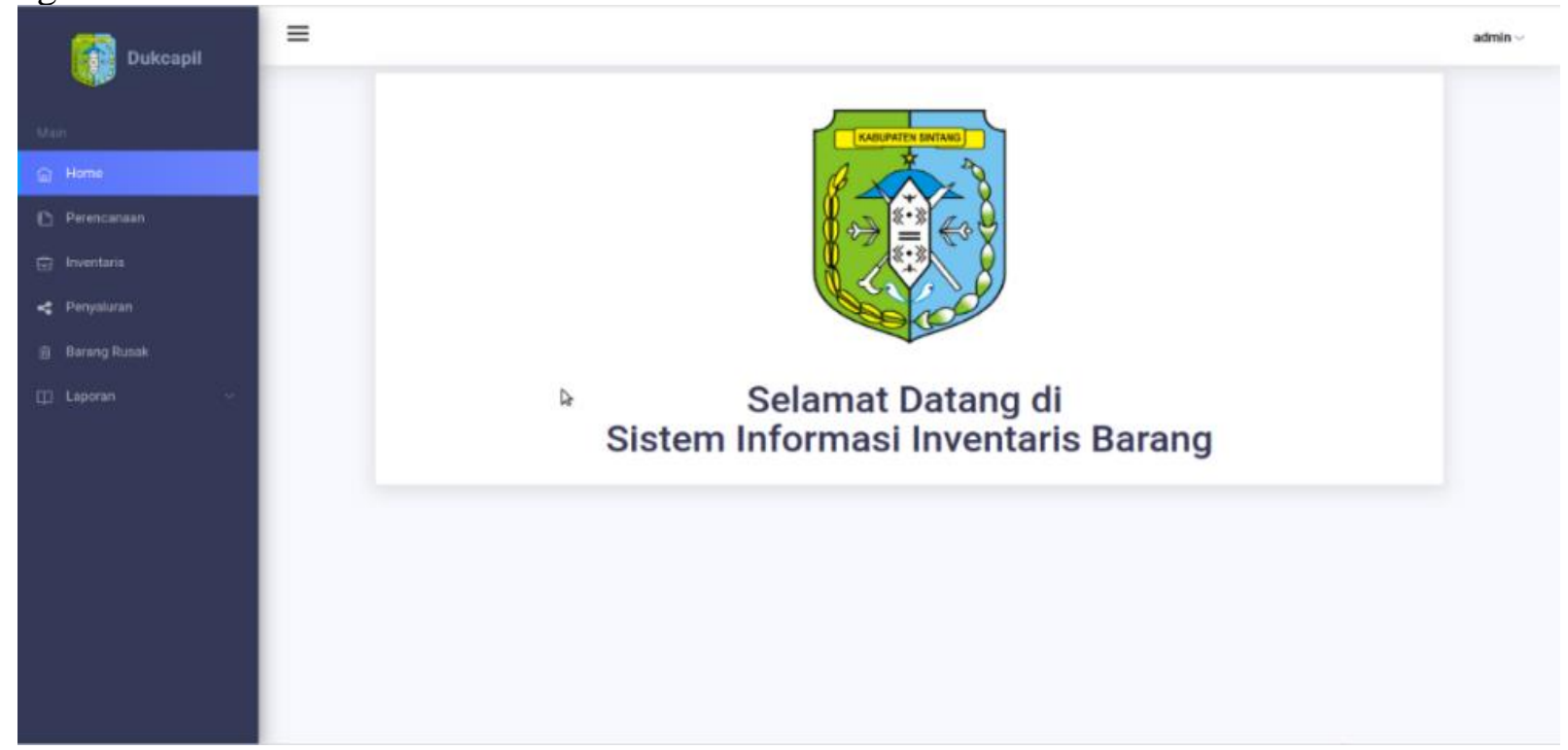

Gambar 8. Login Sukses

\section{Pencarian Perencanaan Barang}

Fungsi pencarian barang digunakan untuk mempermudah dalam melakukan pencarian barangbarang yang telah diinput pada sistem. Fungsi ini akan menjadikan pencarian barang lebih cepat dan tepat. Cara kerja dari fungsi ini adalah dengan mengecek kesamaan kata dari apa yang diketik pada field pencarian dengan yang ada di database. 


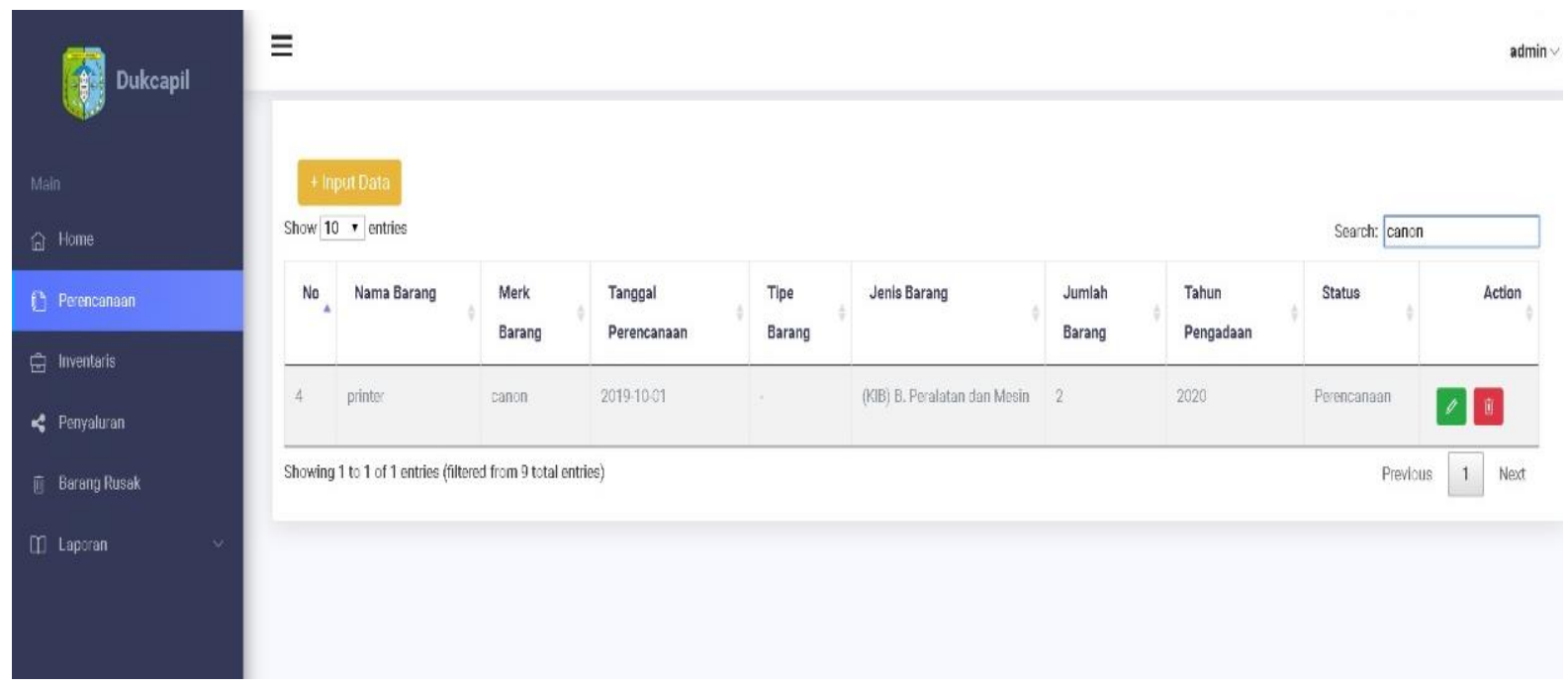

Gambar 9. Form Pencarian Barang

\section{Filterisasi Barang}

a. Filterisasi Perencanaan Barang

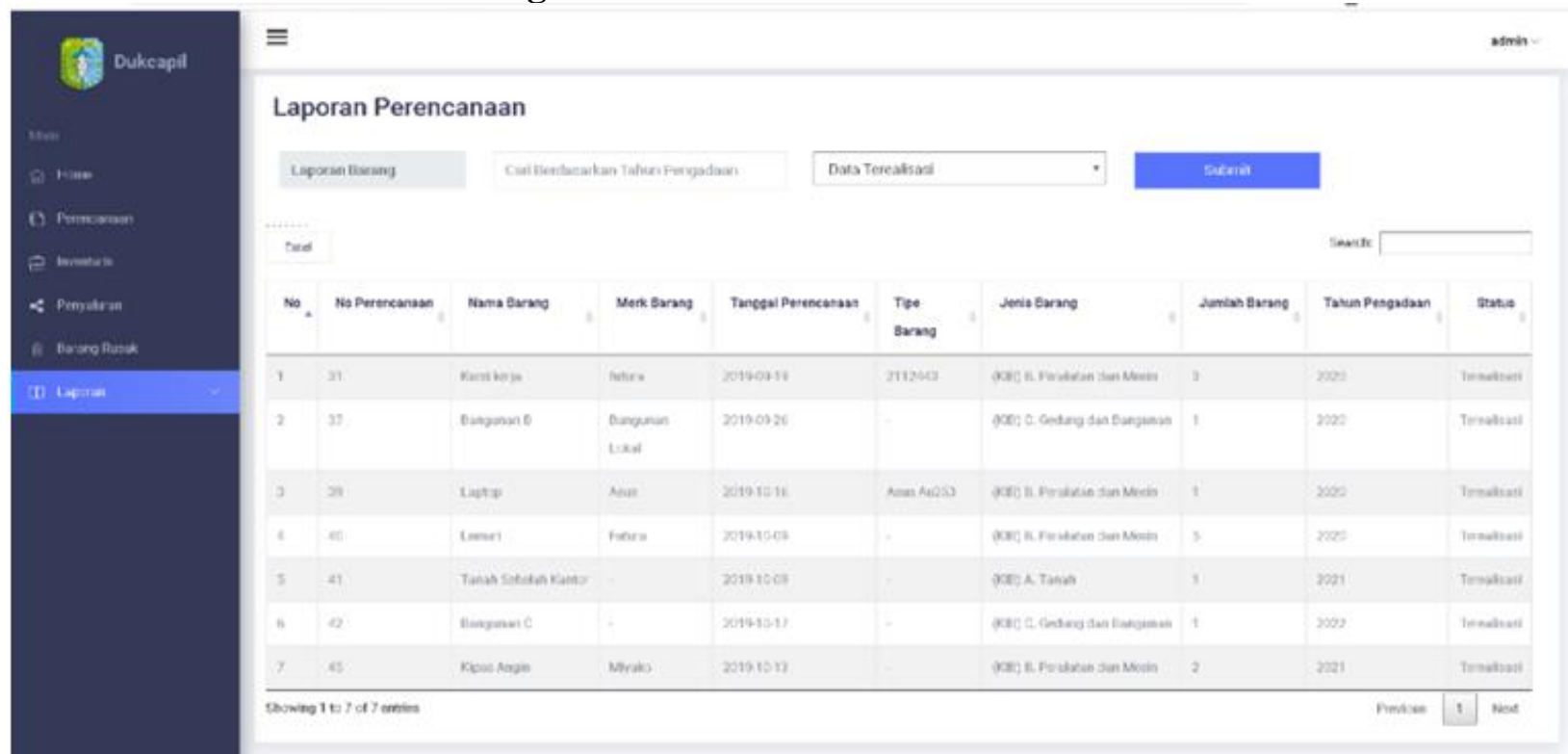

Gambar 10. Filterisasi Berdasarkan Status Perencanaan Barang

Gambar 10 memperlihatkan filterisasi dari status perencanaan barang yang sudah "Terealisasi". Saat proses filterisasi status terealisasi maka sistem secara otomatis akan memfilter data status sesuai dengan apa yang diminta oleh $u s e r$. 


\section{b. Filterisasi Inventaris Barang}

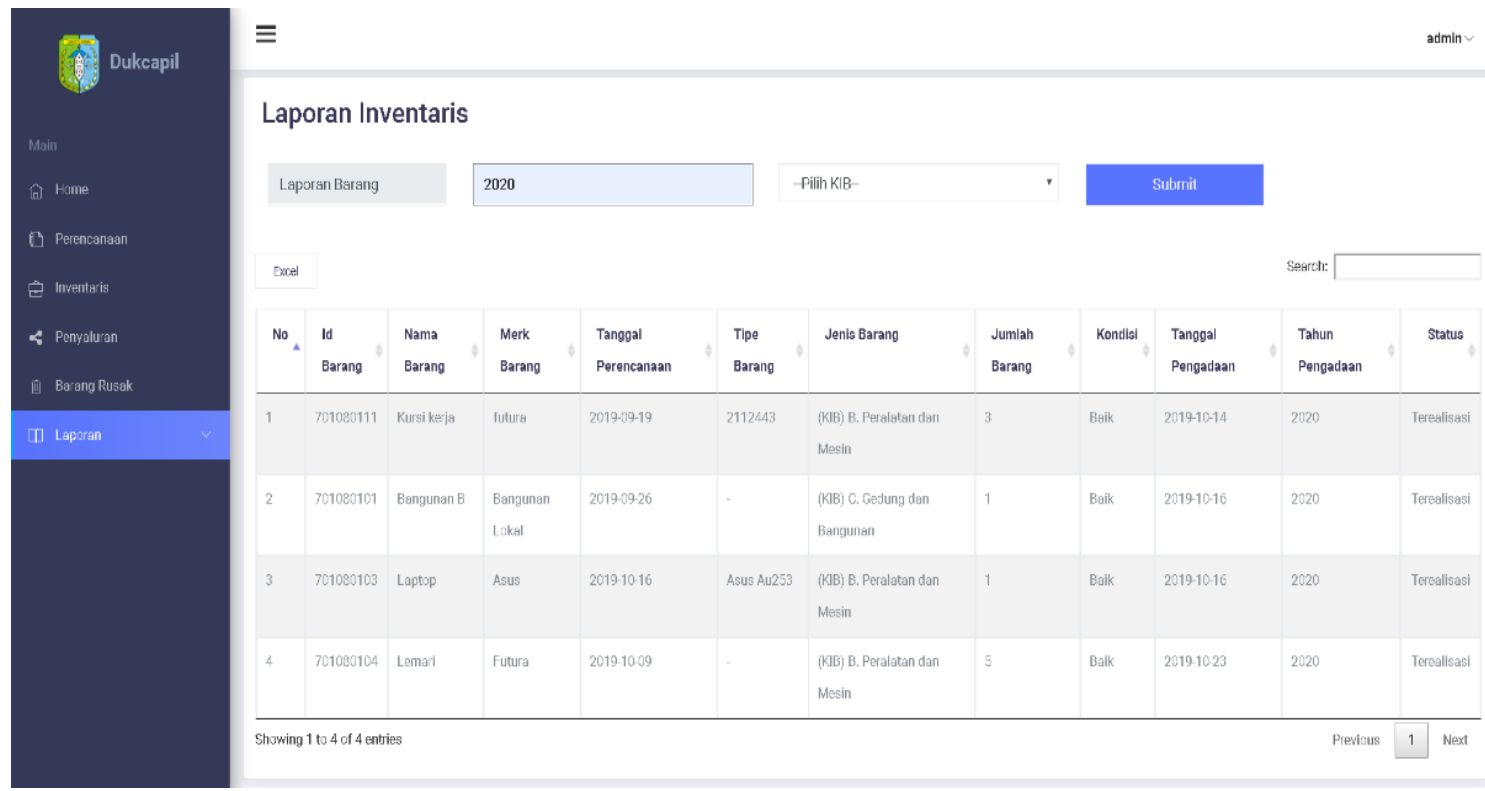

Gambar 11. Filterisasi Berdasarkan Tahun Pengadaan Barang

Gambar 11 memperlihatkan filterisasi pengadaan barang berdasarkan tahun pengadaan barang. Tahun pengadaan yang diinputkan adalah tahun 2020, dan berdasarkan fungsi yang ada, maka sistem secara otomatis akan memfilter sesuai dengan yang diinputkan oleh user.

\section{KESIMPULAN DAN SARAN}

\section{A. Kesimpulan}

Berdasarkan hasil dari analisis, studi pustaka, penentuan kebutuhan, perancangan, dan implementasi rancangan, serta hasil pengujian dari sistem informasi inventarisasi barang pada Disdukcapil Sintang, dapat disimpulkan sebagai berikut:

1. Penggunaan sistem informasi inventarisasi barang pada penelitian ini dapat mempermudah dalam pendataan dan pengelolaan inventaris barang di Disdukcapil Sintang.

2. Penggunaan sistem ini akan meningkatkan efisiensi dan efektifitas kinerja dari pegawai pemerintah yang ada di Disdukcapil Sintang.

3. Peningkatan layanan yang ada di Disdukcapil Sintang dalam hal inventarisasi barang dari segi waktunya lebih cepat dari pada sistem sebelumnya, yakni dengan presentase peningkatan sebesar 99,75\% untuk proses pencarian data dan 99,70\% untuk proses pelaporan inventarisasi barang.

\section{B. Saran}

Saran yang dapat diberikan untuk memperbaiki dan meningkatkan sistem inventarisasi barang yang ada pada Disdukcapil Sintang adalah sebagai berikut:

1. Pihak Disdukcapil Sintang secara berkala harus membuat laporan inventarisasi barang dan mengarsipkannya sebagai bukti fisik inventarisasi barang.

2. Peneliti selanjutnya dapat menggunakan framework yang lebih baik dan andal untuk pengembangan sistem lebih lanjut.

3. Interface dari sistem informasi inventarisasi barang ini dapat dibuat lebih menarik. 


\section{DAFTAR PUSTAKA}

[1] O’Brein, James A., 2005, ’Pengantar Sistem Informasi”, Penerbit : Salemba 4, Jakarta.

[2] Turban, Efraim; McLean, Ephraim; dan Wetherbe, James, 1999, Information Technology for Management, New York: John Wiley \& Sons, Inc.

[3] Zakiyudin, Ais, 2011, Sistem Informasi Manajemen, Jakarta: Penerbit Mitra Wacana Media

[4] Harsono, dkk. 2004.Administrsi Perkantoran 1.Bandung: Alqaprint.

[5] Siregar, Doli D. 2014. Manajemen Aset. Jakarta. Gramedia Pustaka Utama

[6] Aminudin. 2015. Cara Efektif Belajar Framework Laravel. Lokomedia. Yogyakarta

[7] Sukamto,dan M. Shalahuddi, 2013, Rekayasa Perangkat Lunak Terstruktur Dan Berorientasi Objek, Bandung: Informatika.

[8] J. W. Satzinger, R. B. Jackson and S. D. Burd, 2011, Systems Analysis and Design in a Changing World, Sixth ed.

[9] Adi Nugroho. 2010. Rekayasa Perangkat Lunak Berbasis Objek dengan Metode USDP. Andi. Yogyakarta

[10] Sukamto,dan M. Shalahuddi, 2013, Rekayasa Perangkat Lunak Terstruktur Dan Berorientasi Objek, Bandung: Informatika.

[11] A.S Rosa dan Salahuddin M, 2011. Modul Pembelajaran Rekayasa Perangkat Lunak (Terstruktur dan Berorientasi Objek), Modula, Bandung. 